\title{
RESHAPING ECONOMICS TO ENCOMPASS QUALITY OF LIFE ISSUES
}

ŚLĄSKI

PRZEGLĄD

STATYSTYCZNY

Nr 13(19)

ISSN 1644-6739

e-ISSN 2449-9765

DOI: $10.15611 /$ sps.2015.13.10

\begin{abstract}
Summary: In this paper we have given a short account of the shortfalls of neoclassical economics, far removed from Aristotelian political economics, which was considered by him as the art of household management. The objective of it was a flourishing life or the Good Life. The main aim of humankind is the development of a desirable way of living and sustaining the quality of life, also for future generations. In order to achieve that goal, people created a number of institutions to facilitate achieving that end. All institutions, as they are devised for human purposes, cannot be outside human control, they should serve society. In the paper it is argued that the economy, as one of the social institutions, should play a particular role in enhancing human and non-human well-being. The paper contains the proposal of a unified system of measuring institutional and eco-system performance. Moreover, it is argued that among many proposals for the development of new proposals for studying economic matters, ecological economics is the most suitable for researching into the quality of life.
\end{abstract}

Keywords: quality of life, neoclassical economics, ecological economics, sustainable development, performance measurement.

\section{Introduction}

The problems related to human life, particularly those linked to the Good Life, have been discussed since ancient times. Quantitative descriptions of social questions were initiated as early as the 1830 s, and have been embraced in the form of moral statistics. These researches received a new energy in the early 1960s. In this period a social indicators movement sprang up. In the 1970s it was effectively supplemented by the emergence of the concept of perceptual indicators. Unfortunately, due to political reasons, funds for the research of social questions were drastically reduced. Therefore, practically the whole movement was over in the 1980s. This was especially true for the USA.

By the 1990s, mainly due to grass-roots initiatives, the old movement was revived in a new form. It was really a worldwide 
movement, supported by both academics and political organizations. The new wave of social ferment has a number of forms labeled with a number of slogans. Names such as Human Development, Social Progress, Social Cohesion, Subjective Quality of Life, Sustainable Development, Progress of Societies, Quality of Society are used besides the commonly used Quality of Life (see also [Ostasiewicz 2013]).

The diversity of social movement is so broad that it is hardly possible to give a complete analysis of it. The non-governmental sector, individual persons and international organizations all play a significant role in it. Whereas the activity of the UN, the OECD, and of the European Commission focuses rather on the practical side of what and how to measure, the Council of Europe is engaged in highlighting more fundamental aspects of humankind's existence, both from the scientific and philosophical perspective.

On the other hand, a science called "political economy" was developed, renamed "economics". It emerged in ancient Greece, and was aimed at helping people to obtain and properly use the goods necessary for a good life. With time the old science developed more and more, together with a number of schools. It is interesting that all the strands of economics made use of the market mechanism, treating it as a main tool for competition, a prerequisite for economic development. It is however puzzling that economists were reluctant to use this mechanism themselves, to exchange the ideas and allow them to compete. Instead, only one monopolistic view prevails, which is called mainstream economics, suggesting that all the rest is a mere trifle.

Ironically enough, the essence of the science of the Good Life was created by Aristotle in a form of knowledge called economics. For Aristotle, the primary aim of economics was the action of using things required for the Good Life. Even in the beginning of the 20th century, A. Marshall treated economics in the same way. In 1920 he wrote (see also [Marshall 1920, p. 6]):

"Economics is a study of mankind in the ordinary business of life; it examines that part of individual and social action which is most closely connected with the attainment and with the use of the material requisites of wellbeing".

Unfortunately, all the noble intentions of this science were abandoned. Economics stopped being a science of both mankind's problems or of anything related to the real world. Such an opinion is 
shared by a number of those who received the Bank of Sweden Prize in Economic Sciences in Memory of Alfred Nobel.

It is well known that scientists have little impact on politicians and STATYSTYCZNY policy-makers. The only visible force being able to influence policymakers is in the possession of economists. In order to control (drive) the economy's machine, politicians are used to observe the dashboard of gauges, suggested by economists. On the dashboard there are three gauges measuring growth of wealth, innovation, and consumer sentiments. All these indicators are pro-consumer and market oriented. A radical, but also ideal, solution to achieve the orientation from economical to social, would consist in replacing "economic" gauges with "social" measures. The corresponding social trinity could be the following: livelihood of the planet, social engagement (initiatives), and citizen (instead of consumer) sentiments. A realistic solution, proposed in this paper, consists in the integration of both types of indicators. The approach of ecological economics seems to be the most appropriate for defining the framework for an integrated system of indicators.

The simplest justification of this choice is that this kind of economics is embedded in the biophysical universe. Moreover, ecological economists adhere to the methodological pluralism, they are also very critical of the value monism.

The paper is organized as follows. After a brief overview of the development of economics, by means of a simple model taken from growth theory, we try to confirm what was asserted in 1999 by R. Coase, a Nobel Memory Prize winner, namely that "existing economics is a theoretical (meaning mathematical) system which floats in the air and which bears little relation to what happens in the real world" [quoted in Lawson 2007, p. 252]. Then, new trends in economics are briefly sketched. The paper finishes with a proposal of a new way for developing the science of the good life.

\section{From political economy to neoclassical economics}

Modern terms "economics" and "economy" are derived from the ancient Greek word "ekonomike", which is a mix of two words: eikos and nomos. It was used to denote an the art of household management. Households were natural human cooperative associations, embodied into a wider social structure known as polis, city-states. Economics was therefore extended as far as polis. This 
term was used for the first time in 1615. At the beginning of the XIX century, it changed to the term economics. Originally, Aristotelian economics was considered as a fundamentally moral science. The father of so-called classical economics, A. Smith, was influenced by the Aristotelian view on that science. Not only him, but all other classical economists combined philosophical and political issues with economic issues. Economists were considered as worldly philosophers, because of the breath and moral depth of economic enquiry, just as in an influential, highly readable book The worldly philosophers: the lives, times and ideas of the great economic thinkers, published in 1953 R. Heilbroner (see [Heilbroner]). Among such thinkers one finds A. Smith, K. Marx, J.M. Keynes, A. Marshall, and J.S. Mill. All of them were involved in important public policy issues relevant to bettering the lives of people.

Unfortunately, this very noble, prime goal of economics aimed at supporting the good life, has been gradually downplayed and abandoned. Already in $1849 \mathrm{~T}$. Carlyle described economics as a rueful or dismal science, because economics became a science in which all human problems are reduced to "supply-demand analysis". He caricatured this science saying that it is enough to teach a parrot the terms supply and demand in order to make an economist.

All economic activity is designated to create supply for the market, the economy produces not with the aimof meeting people's needs, but for the markets. Marketers are able to create any demand, to turn people into "mindless consumers" of goods that they do not want. K. Polany observed that fictitious commodities like land, labor and money make human social life dependent upon the fluctuations of the market. Recently, also people themselves are becoming commodities. A human billboard is a very mild example, by this expression one means persons who are willing to place a temporary or permanent tattoo on their body for advertising purposes. Not only economy's outputs, but many of the society's highly essential constituents, are transformed into commodities. Not only the above-mentioned above space on human body is being sold for ads, but even cadavers are transformed into commodities. The market economy has given rise to market society, meaning that the whole of society is embedded in the mechanism of its own economy. This is presented in Figure 1.

Any science, particularly any social science, coexists with different schools of thought, or with a number of preferred approaches. As far as economics is concerned, there were, from the 


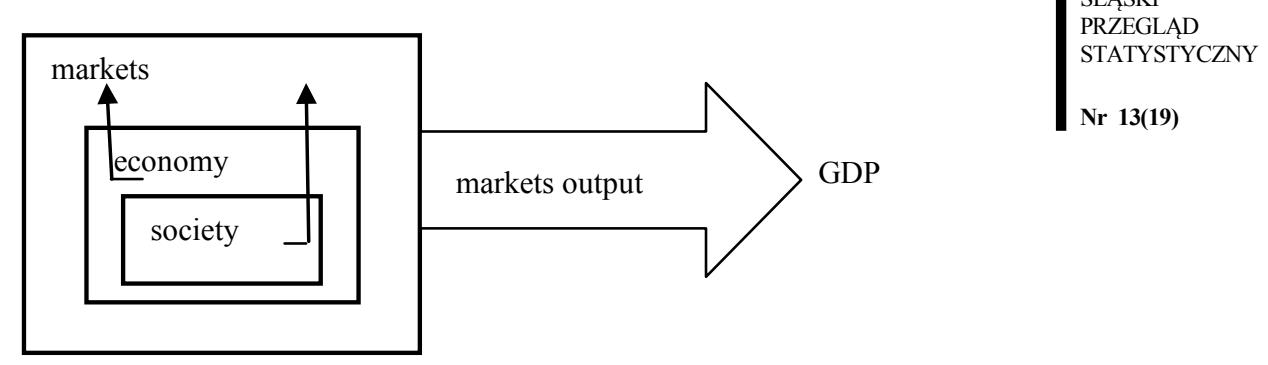

Figure 1. Production for markets

Source: own work.

very early beginning of its development, different points of view on it, only some of them reached the level to be termed as schools of thought. Among all those having this privilege, the school of neoclassical thought has conquered all the others. For this reason it has been seen as mainstream economics. It has never been defined, and it is impossible to identify it precisely. The description of it which seems to be the closest to reality is given by David Deuquech: mainstream economics is considered a form of knowledge, supported by the prestige of the universities in which it is thought and of the journals in which it is published. D. Colander gives a practical criterion to identify it: these are ideas that the elite in the profession find acceptable [Colander 2000].

Neoclassical economics is meant to be about policy design, to be a guide for decision makers. In the case of individual decision makers, economics offers a tool called Cost-Benefit Analysis. The abbreviation CBA, within the circles of mainstream economists, needs no explanation.

In the case of collective behavior, this sort of economics has a magic tool known as the invisible hand, which carries the whole system into an equilibrium state. The notion of equilibrium gained the status of a magic charm. There were distinguished two kinds of equilibrium: partial and general. The latter cemented the whole of the so called welfare economics.

\section{Thinking in terms of models}

The neoclassical strand of economics almost completely lost its real grounding. Neoclassical economics became a theoretical system which, as R. Coase (mentioned above) asserted, floats in the air and 
bears little relation to what happens in the real world. The solutions offered by neoclassical economists are sterile, precise and elegant from the mathematical point of view. It seems, however, it is much more useful to formulate and highlight the real problems, which concern the lot of human beings, even without giving solutions to them, rather than using exact mathematical methods to obtain the exact solution to fictitious, abstract problems. The following wellknown anecdote illustrates this perfectly. Someone met an economist searching under the lamppost for his key, although he lost it somewhere else, but he was searching for his key where the light was. Despite the obvious evidence of the failure of neoclassical economics, there are still numerous adherents to it.

According to J.M. Keynes, economics is the science of thinking in terms of models. How far away neo-classical models are from reality one can easily see from one of the simplest growth models. Suppose that the economy consists of two sectors. One of them is formed by the owners of natural resources, which are used as an input for production. The second sector uses natural resources together with human made capital to produce goods. A graphic presentation of such an economy is shown below

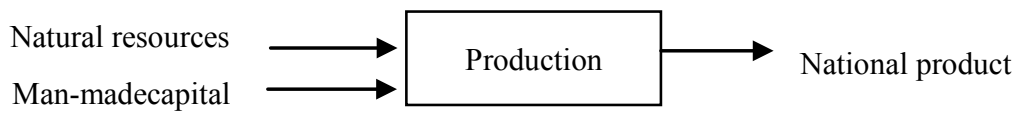

Figure 2. Production scheme

Source: own work.

The prevalent assumption of neo-classical economics is that the sole source of well-being is consumption. It is rather natural to assume that natural resources are limited. In light of these two assumptions the following question is rather obvious: is an economy with exhaustible resources able to provide non-decreasing consumption now and for all future generations?

Economists have proved the following Theorem:

if owners of resources are rational and the society reinvests the rents from non-renewable natural resources into other forms of capital, then society can sustain a constant level of consumption that can go on forever. 
It looks very nice, and seems to be reasonable too. This optimistic result is proved however by using advanced mathematical methods. Normally these methods are not included in curricula for economists' STATYSTYCZNY education, so that for an average student it is impossible to see how abstract this theorem is, how distant it is from reality.

Without going into detail, below there are specified explicitly and formally, all the assumptions underlying this highly optimistic statement. Before listing them, some explanations are presented. First of all, all the basic notions like production, consumption, investment, and extraction, are represented by functions of time, so that they are treated as processes.

The system of three functions $P=(c(t), k(t), r(t))$ considered as the mapping (multifunction): $P: R_{+} \rightarrow R_{+} \times R_{+} \times R_{+}$will be called a time path (of consumption, investment, and extraction) starting from the initial stock $S_{0}$, and initial capital $K_{0}=k(0)$. All possible paths are denoted by $\Phi\left(K_{0}, S_{0}\right)$. If there exists such that $c(t)=c$ for all $t \in[0, \infty)$, then a path $(c(t), k(t), r(t)) \in \Phi\left(K_{0}, S_{0}\right)$ is called the egalitarian path. A path $(c(t), k(t), r(t)) \in \Phi\left(K_{0}, S_{0}\right)$ is said to be a maximin path or Rawlsian path if the inequality

$$
\inf \{c(t) \mid t \in[0, \infty)\} \geq \inf \left\{c^{\prime}(t) \mid t \in[0, \infty)\right\}
$$

is satisfied for all paths $\left(c^{\prime}(t), k^{\prime}(t), r^{\prime}(t)\right) \in \Phi\left(K_{0}, S_{0}\right)$.

If a path $(c(t), k(t), r(t)) \in \Phi\left(K_{0}, S_{0}\right)$ satisfies the Hartwick rule, then it is called the Hartwick path.

Suppose now that economics described by the triple $P=(c(t)$, $k(t), r(t)$ ), and the production function $F(k(t), r(t)) \in R_{+}$fulfills the following assumptions (see [Asheim et al. 2003; Mitra 2012]). holds

1. Consumption is a functionc: $R_{+} \rightarrow R_{+}$, such that for any $t \in[0, \infty)$

$$
\lim _{\tau \rightarrow t} c(\tau)=c(t) .
$$

2. Extraction of natural resource is a continuous function $r: R_{+} \rightarrow R_{+}$

3. Stock of man-made capital is a continuous and differentiable function $k: R_{+} \rightarrow R_{+}$

$$
\lim _{\tau \rightarrow t} k(\tau)=k(t), \lim _{\tau \rightarrow 0} \frac{k(t+\tau)-k(t)}{\tau} \geq 0 .
$$

4. Remaining stock of exhaustible resource is a function defined as follows 


$$
s(t)=S_{0}-\int_{0}^{t} r(\tau) d \tau
$$

Nr 13(19)

where $S_{0}$ is the initial, at the present time, level of natural capital.

5. Natural capital is exhausted in indefinite (infinite) time

$$
\lim _{T \rightarrow \infty} \int_{0}^{T} r(\tau) d \tau \leq S_{0}
$$

6. Production is defined by a function $F: R_{+} \times R_{+} \rightarrow R_{+}$ which for any input $(k, r) \equiv(k(t), r(t)) \epsilon R_{+} \times R_{+}$assigns an output $F(k(t), r(t)) \epsilon R_{+}$and for any $t>0$ fulfilled the following conditions

$$
\begin{aligned}
F(0, r(t))= & F(k(t), 0)=0, \frac{\partial F(k, r)}{\partial k}>0, \frac{\partial F(k, r)}{\partial r}>0, \frac{\partial^{2} F(k, r)}{\partial k \partial r}<0, \\
& \text { inf }\left\{\frac{\partial F(k, r)}{\partial r} \frac{1}{F(k, r)} \mid(k, r) \in R_{+} \times R_{+}\right\}>0 .
\end{aligned}
$$

7. In any period $t \epsilon[0, \infty)$ the Hotelling rule is fulfilled

$$
\frac{\partial F(k(t), r(t))}{\partial t}=\frac{\partial F(k(t), r(t))}{\partial k} \cdot \frac{\partial F(k(t), r(t))}{\partial r} .
$$

8. In any period $t \in[0, \infty)$ the Hartwick rule is fulfilled

$$
\frac{\partial F(k(t), r(t))}{\partial r} r(t)=F(k(t), r(t))-c(t) .
$$

9. The development of the economy is described by two differential equations:

$$
\begin{gathered}
\frac{d k(t)}{d t}=F(k(t), r(t))-c(t), t>0, \\
\frac{d s(t)}{d t}=-r(t), t>0 .
\end{gathered}
$$

Even a cursory reading of these requirements reveals that $\mathrm{R}$. Coase was really right in asserting that the economy seen in that way bears almost no relation to a real economy. The assumptions listed above permit, however, to prove an important theorem about unlimited economic growth.

The necessary and sufficient conditions for the existence of different kinds of paths are very complicated. For the aim of this paper it will be sufficient to consider a very special variant of the production function. Suppose that production is described by the Cobb-Douglas function

$$
Q=F(k, r)=[k(t)]^{\alpha} \cdot[r(t)]^{\beta}, \alpha+\beta \leq 1 .
$$


If $\alpha>\beta$, then maximum egalitarian consumption is given by the formula

$$
c_{0}=(1-\beta)\left[(\alpha-\beta) \cdot S_{0}\right]^{\frac{\beta}{1-\beta}} K_{0}^{\frac{\alpha-\beta}{1-\beta}} .
$$

The extraction level is defined by the equation

$$
r(t)=\left(\frac{c_{0}}{1-\beta}\right)^{1 / \beta} \cdot[k(t)]^{-\alpha / \beta} .
$$

Using (1), we can determine the stock of natural resource in any instant of time, and from (4), the state of capital in any instant of time.

The marginal productivity of resource in the case of the CobbDouglas function is

$$
\frac{\partial F(k(t), r(t))}{\partial r}=\beta[k(t)]^{\alpha} \cdot[r(t)]^{\beta}=\beta k^{\alpha} r^{\beta-1} .
$$

The rents from the resource are calculated as

$$
\text { rents }=\text { productivity } \cdot \text { extraction }
$$

So that one has

$$
\frac{\partial F(k(t), r(t))}{\partial r} r(t)=\beta k^{\alpha} r^{\beta-1} \cdot r=\beta k^{\alpha} r^{\beta} .
$$

The Hartwick rule requires that this amount of production must be reinvested:

$$
\text { investment }=\frac{d k(t)}{d t}=\beta \cdot[k(t)]^{\alpha} \cdot[r(t)]^{\beta}
$$

And the rest of production can be consumed, this 'rest' is equal to the quantity

$$
\text { consumption }=(1-\beta)[k(t)]^{\alpha} \cdot[r(t)]^{\beta} .
$$

The dynamics of that economy is depicted in Figure 3

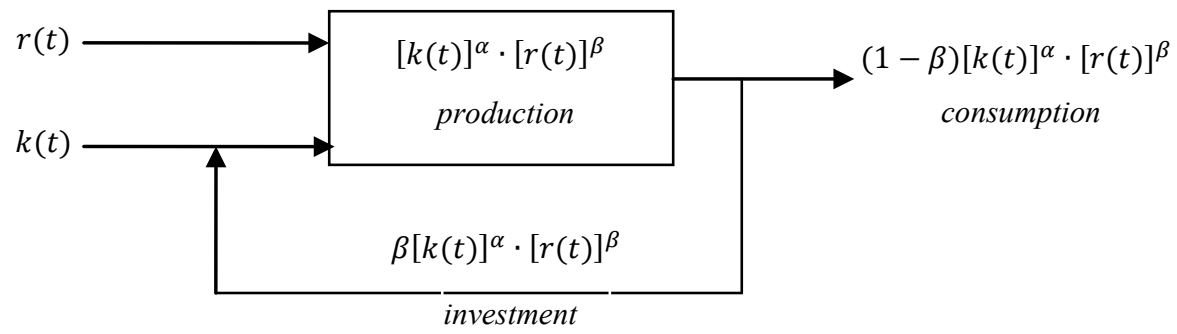

Figure 3. One-sector economy

Source: own work. 
Example.

Suppose that $S_{0}=1, K_{0}=1$, and $\alpha=0.7, \beta=0.3$, then the consumption enjoyed by all generations, at any instance of time, given by (7) is the following:

$$
c_{0}=(1-0.3)[(0.7-0.3) \cdot 1]^{\frac{0.3}{1-0.3}} 1^{\frac{0.7-0.3}{1-0.3}}=0.473
$$

the processes of resource extraction, determined by (8) is

$$
r(t)=\frac{5.931}{(12.931+3 \mathrm{t})^{1.207}}
$$

Stock of man-made capital, $k(t)$, and stock of natural resource, $s(t)$, one obtains correspondingly from (4) an (1). For this particular case, differential equation (4) takes the form

$$
\frac{d k(t)}{d t}=[k(t)]^{\alpha} \cdot[r(t)]^{\beta}-c_{0}
$$

from which one obtains

$$
k(t)=0.266(12.931+3 t)^{0.517} .
$$

From (1) results the following solution:

$$
s(t)=1-5.931\left(0.949-\frac{1.611}{(12.931+3 t)^{0.207}}\right) .
$$

The graphics of these three functions are presented in Figure 4.

$r(t)$ resource extraction

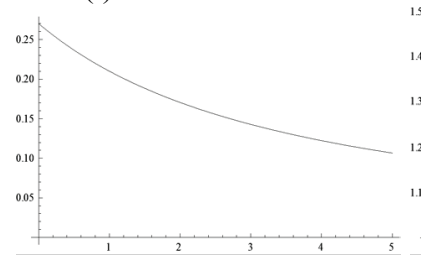

$k(t)$ investment

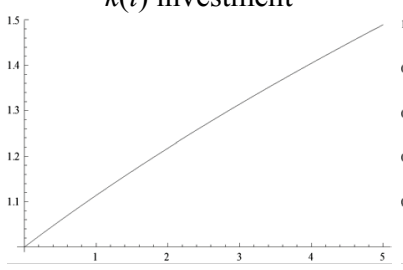

$s(t)$ remaining resource

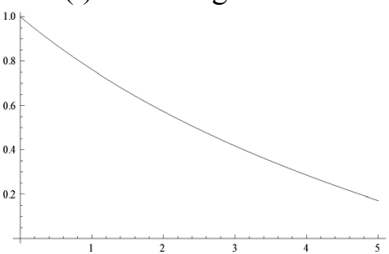

Figure 4. Extraction, investment, and consumption processes

Source: own work.

This highly "optimistic" result about exponential growth is mainly due to Hartwick. It became very famous and attractive because it gave an essential extension to the basic result of the theory of growth proposed by Solow [1974]. The Hartwick result means that exhaustible resources can be substituted by human-made capital in 
such a way that the depleting natural resources will cause no harm for future generations, as constant consumption can be sustained forever. So that it is fully acceptable that the last fish used for the production STATYSTYCZNY can be substituted by a fishing rod.

In order to see how unrealistic the assumptions underlying the consideredTheorem are, we list below only a few critical observations.

1. All consumers are equal, so there is considered only one infinitely lived representative individual

2. The producers(owners of capital) are also equal, represented by one infinitely lived owner who decides now about the prices in the future. The theorem is based on the famous Hotelling rule [Hotelling 1931], but the rule itself is based on the assumption: "Since it is a matter of indifference to the owner of a mine whether he receivesfor a unit of his product a price $p_{0}$ now or a price $p_{0} e^{\gamma t}$ after time $t$, it is not unreasonable to expect that the price $p$ will be a function of the time of the form $\mathrm{p}=p_{0} e^{\gamma / t}$ [Hotelling 1931].

3. The innocent, but hidden assumption is the following: at any instant of time future generations will be continuously wealthier and wealthier.

4. Hartwick's investment rule requires massive government, or a central planner's, intervention in the capital market; second, it is not clear how much should be invested by the private sector versus public investments. The important objection is that the commitment to invest resource rents now cannot commit future generations to do the same, and in the same manner.

If these assumptions are fulfilled, then the growth of capital will continue forever. The best comment about this Theorem isDaly's famous saying: "if wishes were horses, then beggers would ride".

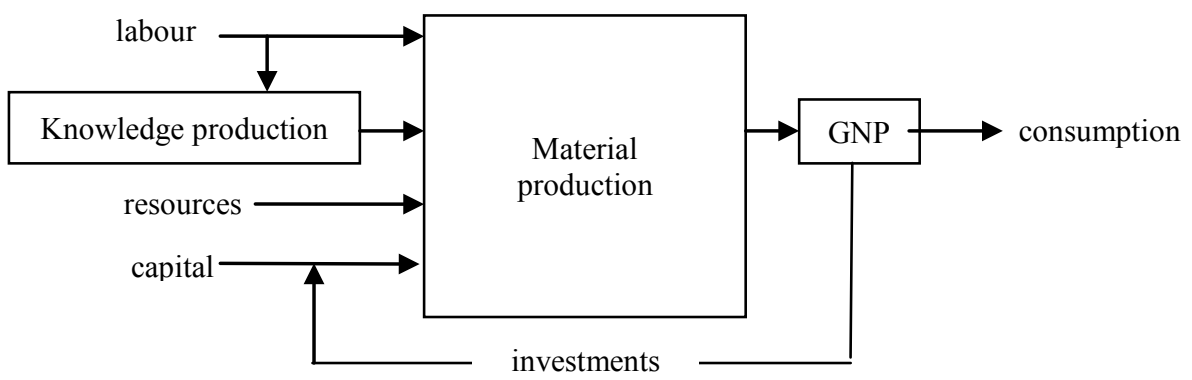

Figure 5. Scheme of endogenous growth theory

Source: own work. 
PRZEGLAZD STATYSTYCZNY

Nr 13(19)

As one can see from (8), resources are steadily decreasing. Economists have invented an inexhaustable resource, called technology and knowledge, which is "produced" in a separate private sector. In that way one arrives at a so-called knowledge-based economy. In this economy,knowledge accumulation needed for steady growth is obtained by innovation. This is a new 'spell' used recently, not only by economists. A kowledge-based economy is depicted in Figure 5.

This approach, as opposed to the human capital approach, is based onSchumpetr's theory of knowledge accumulation.

\section{Voices for change}

The concept of growth as a policy objective has been used since the end of the 1950s, before 1950 it was hard to trace interest in growth in the official or professional literature [Arnd cited by Victor]. Now it is obvious how much damage has been created economic growth. It has also been recognized that the current economic system has failed, and economics as a science, too. "Modern economics is sick. Economics has increasingly become an intellectual game played for its own sake and not for practical consequences for understanding the economic world" (see [Blaug 1997]).

A new idea began to crystallize about 50 years ago. The first significant contribution was made by Karl Polany (1886-1964). In his book "The great transformation, the political and economic origins of our time" published in 1944, K. Polany thoroughly examined and explained the defects of economics. He observed that the dynamic of modern society was governed by a double movement. The first was an expansion of the market. The second movement was the countermovement against "satanic mills", this was the self-protection of society against a self-regulating market. It was K. Polany who observed that the whole of economic activity is destined to create supply on the market, the economy produces not with the aim of meeting people's needs, but for the market's. Polany's book remained unfortunately unnoticed for many years. By the end of the 1950s there emerged a wider rebellion against the market's hegemony. In 1958, J.K. Galbright published a book exploring the big difference between private affluence and social squalor. In 1965, Bertram M. Gross was also among the the first who voiced for change, he argued that economists using their "economic analysis" excluded all the important 
aspects of social life. The tendency of using the omnipotent monetary rod for measuring social phenomena was described as a new Philistinism. B.M. Gross initiated the world-wide movement of social STATYSTYCZNY indicators, which was however hindered by the rise of Reaganomics. The other reason for the hibernation of that movement was that it arose outside the domain of eonomics. Galbright was regarded as a political commentator, and was therefore ignored by academic economists (see Victor 2008). A very firestorm was set off in 1967 by Ezra Mishan with his book "The costs of economic growth". He was a well-respcted economist, his view was therefore taken seriously in the circle of mainstream economics. Mishan's book "was an urgent plea to thoughtful people to ponder the effects on the welfare of ordinary people of a gathering erruption of science and technology in pressure sufficient to splinter the framework of our institutions and to erode the moral foundations on which they have been raised" [Haines 2013]. The next economist, who provided an extremally sharp critique of a modern industrialized economy was E.F. Schumacher, in his book Small is beautiful: a study of economics as if people mattered, published in 1973 (see also [Phelps 2007]).

The economic system functions in interaction with other systems, and as all the other social institutions, is embedded in the environmental system. The economy includes, as its part, the market mechanisms, and the market must be subordinated to the economy, not vice versa. This view is in accordance with a variant of new economics known as ecological economics, founded by H. Daly (see [Gowdy 2005; Daly 1977]). This alternative to neoclassical welfare economics provides a good foundation for policy recommendation. Vernon L. Smith, when he received the Bank of Sweden Prize in Economics in Memory of Alfred Nobel in 2002 (unjustly, and incorrectly called Nobel Prize), delivered a lecture in which he thoroughly explained the notion of ecological rationality [Smith 2003]. This kind of rationality uses reason to examine the behavior of individuals based on their experience and folk knowledge to apply constructivist tools to the decision they make, but also to understand the emergent order in human cultures that are created from human interactions, but not by deliberate human design. This concurs with the other winner of the same kind of prize, namely M. Allais, who contrasted intelligent thinking with rational, deductive thinking. Ecological rationality based on the ability to exploit the information in the natural environment. T. Lawson defends also the view that the 
social realm, embedded in the natural environment, is emergent from human interaction, but it does not reduce it to human practices. This kind of social system underlies another approach to reshaping neoclassical economics, called green economics [Lawson 2007].

\section{Towards the science of human well-being}

At the beginning of 2008, on the French government's initiative the Commission on the measurement of economic performance and social progress was created. One of the main reasons for creating it was that it raised, for the first time in a long time, the problem of the inadequacy of the current measurement of economic performance by the widely criticized GDP index. The Commission, chaired by Joseph E. Stiglitz, published in 2009 the now famous report [Stiglitz et al. 2009, pp. 11-12]. The report contains two main messages.

The first main message is "that the time has come to adopt our system of measurement of economic activity to better reflect the structural changes which have characterized the evolution of modern economics".

The second key message, and unifying theme of the report, is that "the time is ripe for our measurement system to shift emphasis from measuring economic production to measuring people's well-being".

These two messages are the departure point for this part of the paper. The first essential remark which is stressed here is that Stiglitz's report was written from purely an economists' perspective. The economy is in the center of the whole inquiry, moreover it is considered as an autonomous system alongside two others: social and environmental systems. Instead of the three pillar approach, the socalled Russian dolls model should be applied, with the economy as the most inferior doll, the superior being society. Contrary to Thatcher's infamous assertion that there is no such thing as society, the notion of society plays a central role in the methodology proposed in this paper. The nature of the human beings cannot be reduced to homo economicus. Homo sapiens is above all a social being( homo socialis rather than homo economicus). Moreover, society is considered not as a collection of entities such as people or households, but as a system having emergent properties and superior to any other sub-systems. The only system the societal system is embedded in is the natural system. All other, smaller or bigger systems, created by people, have to be subordinate to society (see Figure 6). By this scheme we tried to 
emphasize the need of replacing the market (economic) slogan, 'supply-and-demand', with societal (humane) battle cry, needs-andmeeting them. Society should be liberated from market's hegemony, and demand has to be liberated from the supply empire.

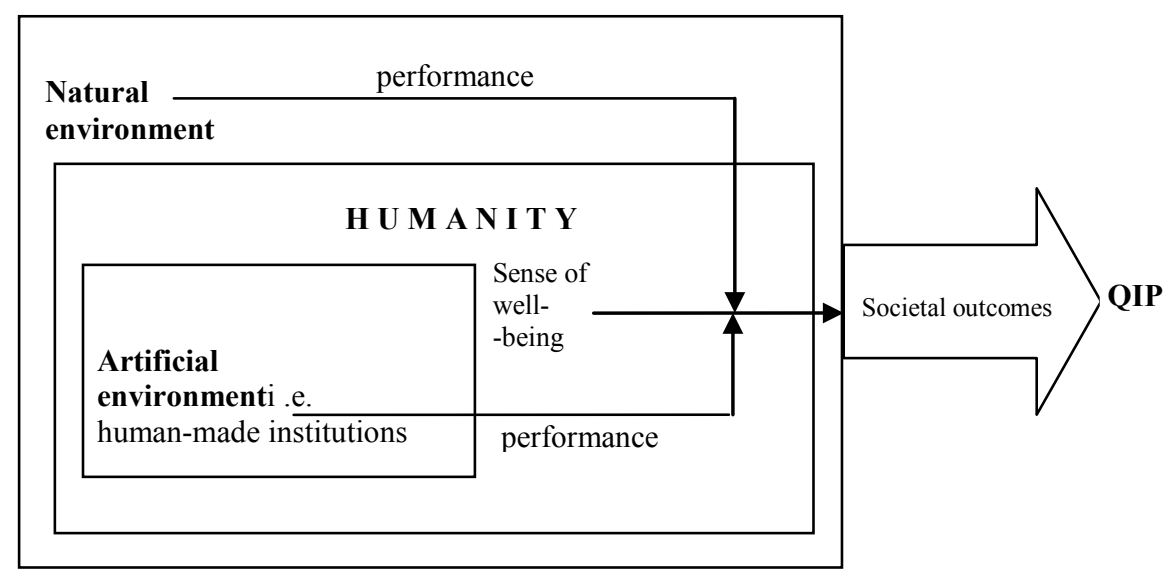

Figure 6. Structural systems suitable for the measurement of well-being

Source: own work.

The economy is only one of the social institutions, and as any of the others, it is designated to perform well-determined tasks, not to produce for the market, but its aim is the betterment of human beings. Economics, as a body of knowledge about this institution, should support the achievement of this goal. This means simply that economics should be considered as the science of human beings. Usually the term of well-being is used. For many people a much more appropriate term is the term of ill-being, so that the term human being seems to be more suitable than human well-being.

The efforts to create such economics have recently been undertaken by a number of institutions, chiefly of the NGO type, and even by individual persons. For some it is socionomics, for others it is ecological or green economics. In any case, the endeavors are directed towards creating a science aiming to improve the human lot. Already Aristotle had written that just talking about virtue does not make a man virtuous. To become virtuous one has to act. The same can be said about the more modest concept of well-being, where one needs to act. Actions need the guide and the tools. Among all the possible tools, a system of social indicators plays a central role. During the last 
fifty years there have been proposed a number of concepts of social indicators. Almost all the developed indicators are influenced by the utilitarian theory. They are strongly directed towards the maximization of total benefits. An alternative to the utilitarian stand point is the Rawlsian appeal for protecting a minimum level of dignity. A typical utilitarian measure is GDP, a machine that can only add up. This measure has been "corrected" by subtracting undesirable outputs such as pollution, depletion, loss of enjoyment by people etc. The resulting index is the Genuine Progress Index. According to R. Frank, the production of so-called positional goods such as exceedingly expensive watches or yachts is a waste of productive resources, therefore they could be considered as disproducts.

\section{Institutional performance}

The aim of this paper is to sketch a framework of a new methodology of the knowledge acquisition about the quality of the functioning of the whole eco-biological system.

Any methodology presupposes some foundational principles. The first prerequisite of the intended methodology is a systemic approach to all the problems related with the existence of humankind. A comprehensive understanding of human beings requires taking into account all aspects of the totality of life, not just human life. This was summarized by Schweitzer saying Ich bin Leben, das leben will, inmitten von Leben, das leben will ("I am life that wills to live in the midst of life that wills to live"). This standpoint corresponds with Robert Prescott-Allen's approach, as well as the worldwide MA project (see [Millenium 2003]). This simply means that one has to consider simultaneously human well-being, and the ecosystem's wellbeing. By human well-being, we simply mean the condition in which all members of society are able to determine and meet their needs and have a large range of choices to meet their potential (see [PrescottAllen 2001]). Similarly, ecosystem well-being is considered also as "a condition in which the ecosystem maintains its diversity and quality and thus its capacity to support people and the rest of life - and its potential to adopt to change and provide a wide range of choices and opportunities for the future" [Prescott-Allen 2001, p. 5].

Human and non-human beings are not antagonistic, they always were partners in evolution. M. Bookchin, in many of his writings tried to create a unified theory of natural and social worlds [Best 1998]. 
They both should be considered as cooperating systems, and therefore they should be evaluated also as two tightly bound systems, this means they should both be treated from the systemic perspective. The STATYSTYCZNY interactions between people and the ecosystem is presented in Figure 7.

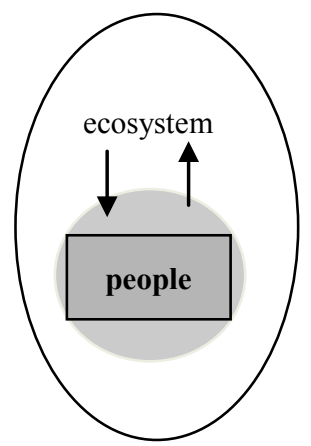

Figure 7. The Egg of well-being

Source: [Prescott-Allen 2001].

Social realm has an emergent structure, the properties of which cannot be reduced to the phenomena from which a system emerged. The system as a whole can suffer illnesses, and its components (people) can also feel unwell. Social ills, environmental burden, harmony, or cohesion are typical collective, systemic characteristics. It is obvious that to survive, human beings need the necessary material, but a good life is something more than only to survive. The five basic factors determining a good life considered in [Millenium 2003] are depicted in Figure 8.

The obvious fact is that well-being is a perversive quality of experience. Therefore, the experience of living and being is located in the centre of the diagram shown in Figure 7. The diagram is borrowed from the description of the world-wide project Ecosystem and human well-being (see [Millenium 2003]), stressing that well-being is determined by these five factors, but they must be delivered to humans, they must be served or produced, and equally distributed. In order to facilitate their lives, people devise various institutions and organizations. All the designated institutions have clearly defined (pre-specified) tasks to perform. All of these institutions and organizations are to be at the service of humankind, therefore it is society that is authorized and obligated to evaluate the quality of these services, as they determine the quality of people's lives. 


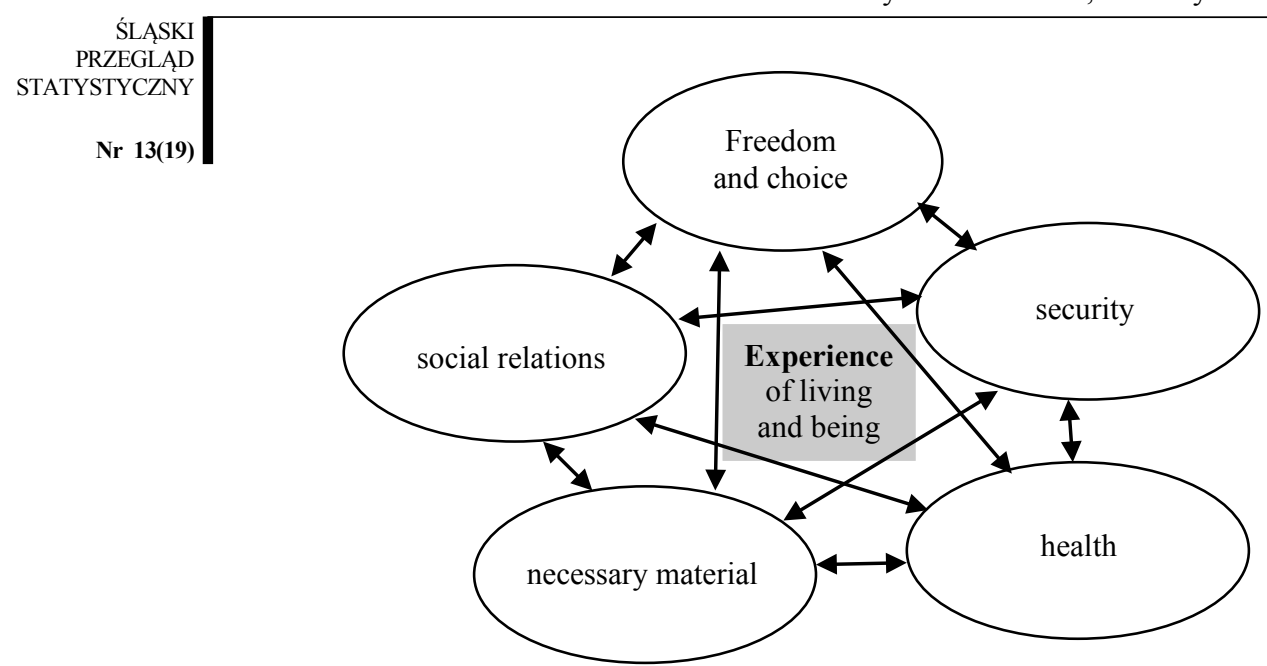

Figure 8. Dimensions of human well-being

Source: adoptation from [Millenium 2003].

In this project it is argued that the assessment of human beings should be made through the assessment of the performance of all the institutions designated by people to provide them with all that they need to ensure at least a decent life. The right to judgement on the human beings belongs only to society, to humans. Society is however in its turn, a very complex system embracing various organizations and institutions. All institutions are designed with the scope of perfoming particular tasks. The quality of human life depends on how these tasks are performed. One needs therefore tools for the performance's measurement. The economy, as one of the institutions created by society should be not the master of people's lives, but the servant of human prosperity. Human beings are authorized to judge the quality of their servants (institutions).

Both the natural environment, or the biophysical system, and the social system are not simply a collection of elements, they are selfregulating very complex systems. They have therefore their inherent characteristics, apart from their performance. These performances, needed and desired by people, depend on the wellness of these systems, their capacity to perform expected tasks. The basic feature characterising the biophysical system is its resilience (see [Ostasiewicz 2013]). For the social system such a synthetic gauge of its state can be cohesion. Social cohesion is strictly connected to inequality. This issue was until recently neglected by social 
researchers, and especially by economists, focusing on growth and wealth considered as a whole. As a key cross-cutting issue that was even neglected in the Millenium Development Goals, it is worth STATYSTYCZNY quoting here E. Neumayer's observation: "Many academics and public intellectuals have recently voiced grave concern about the increasing inequality and its detrimental social effects, not least by it slowly destroying the social fabric and public spirit on which the private and public welfare of all societies are built" (see [Neumayer 2011, p. 1]). The increasing endemic of inequality concerns not only income, but also healthcare, education, personal security, personal activity and the influence on public decision-making, generally in human development. Equality, or more fundamentally, equity, is integral to human development, in new economics a primary subject of concern should be the person, only individuals are the ultimate units of moral concern. Not utilitarianism, but ethical individualism, as promoted by A. Sen, should form the moral base for new economics.

This means that one thing is the measurement of wellness of a natural or social system, and the other thing is the measurement of wellness of people or households. The system of social accounting (some call it social intelligence) proposed in this paper comprises three basic components as its sub-systems:

- Condition (state) and performance of natural eco-system

- State and performance of social system( man-made)

- People's daily-life experience.

People's experience is usually called subjective well-being, but neither well-being nor ill-being can be subjective, we can only talk about perceived being; for that reason we argue for an expression like perceived well-being, or a sense of well-being (see also [Farrel 2008]). The structural system of indicators is presented in Figure 9.

A new feature of this approach consists in adopting a systemic structure for indicators characterising life on Earth as a whole, not merely listing them, but eventually dividing them by dimensions.

The two sub-systems, natural and human-made, offer opportunities for living desired lives. In principle, performance measurement means the measurement of these opportunities. Opportunities, or conditions, form only the basis for good living. They would be useless if people were not able to use them. High culture is but a set of artefacts without persons who can appreciate and interpret it. Quality of living does not depend only on the conditions. As R. Lane rightly observed, quality of 


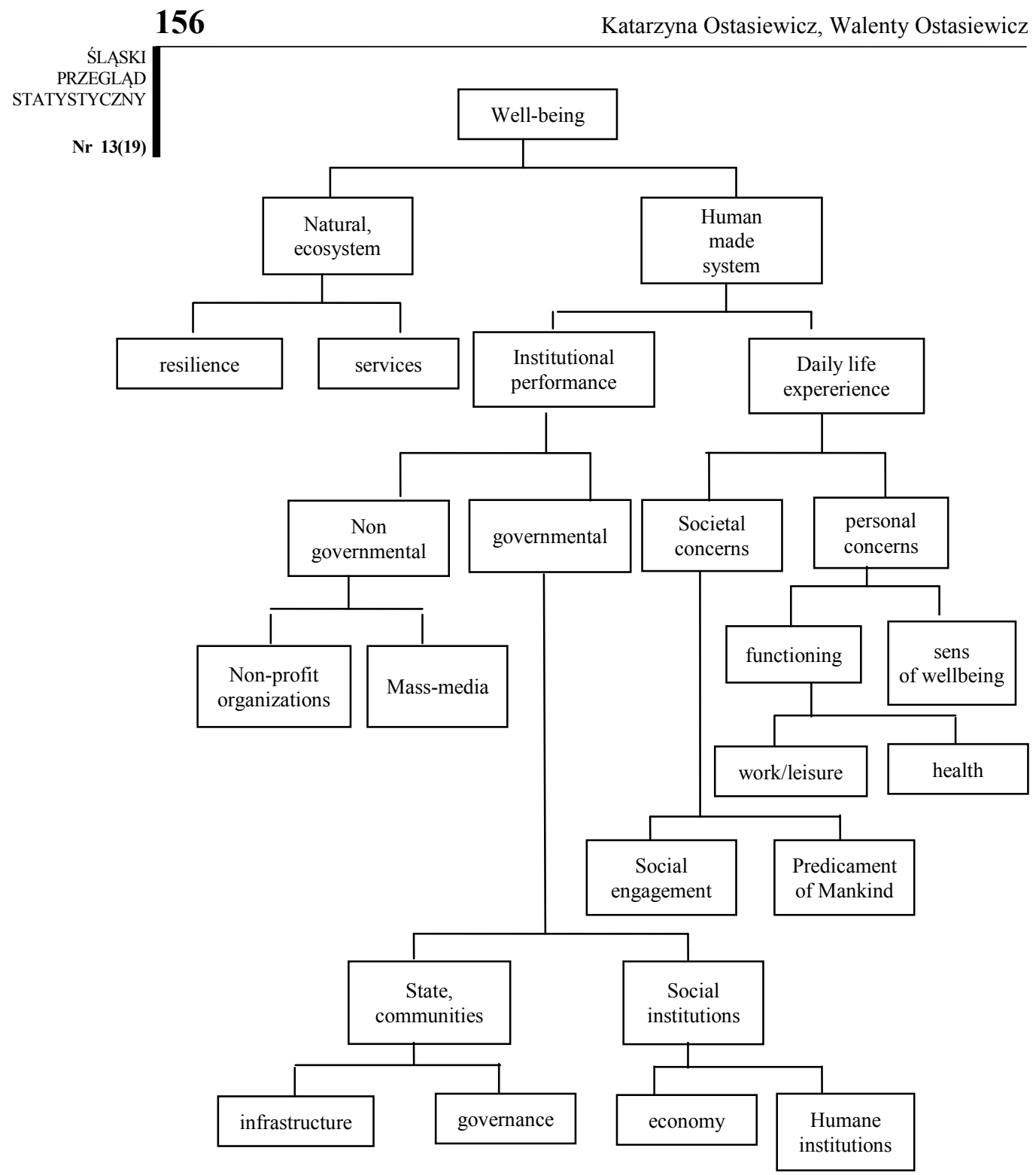

Figure 9. Structural system for performance measurement

Source: own drawning.

life depends also on the quality of the person. In his capability theory, A. Sen points out that freedom is worthless without the capacity and willingness to use it. R. Lane listed nine opportunities, i.e. quality of conditions for quality of living. These conditions are the following [Lane 1996]: adequate material support, physical safety and security, 
available friends and social support secure, opportunities for the expressing and receipt of love, opportunities for challenging work, the kinds and amounts of leisure, available set of moral values that can STATYSTYCZNY give meaning to life, opportunities for self-development, with the assistance of such help as may be needed, objective justice.

The open matter remains how ensure the corresponding properties of quality of person in order that persons will be capable to exploit the opportunities. The other, often discussed problem is the question of self-assessment versus external assessment. The view presented in this paper is as follows: the states and performances are to be assessed externally. These assessments should be confronted with people's perception.

\section{Acknowledgement}

This paper is based on the proceedings [Ostasiewicz, Ostasiewicz 2013] and the NCN Grant proposal 2014/13/B/HS4/01511 rejected as devoid of any scientific value. We are very grateful for Prof. R. Zimka and two anonymous Referees for their very useful suggestions as to improving the original version of this paper.

\section{References}

Asheim G.B., Buchholz W., Withagen C., The Hartwick Rule: Myth and Facts, "Environmental and Resource Economics" 2003, Vol. 25, pp. 129-150.

Best S., Murray Bookchin's theory of social ecology, "Organization and Environment" 1998, Vol. 11, No. 3, pp. 334-353.

Blaug M., Ugly currents in modern economics, "Policy Options" 1997, Vol. 17(7), pp. 2-5.

Chick V., Economics and Good Life: Keynes and Schumacher, "Economic Thought" 2013, 2.2, pp. 33-45.

Cobb C.W., Measurement tools and quality of life, Redefining Progress, June, 2000.

Colander D.C., The death of neoclassical economics, "Journal of the History of Economic Thought" 2000, Vol. 22, pp. 127-142.

Daly H.E., Steady-State Economics, Freeman, San Francisco 1977.

Dasgupta P., Heal G., The Optimal Depletion of Exhaustible Resources, "The Review of Economic Studies" 1974, Vol. 41, pp. 3-28.

Dasgupta P., Mitra T., Intergenerational Equity and Efficient Allocation of Exhaustible Resources, "Intl. Econ Rev." 1983, Vol. 24, pp. 133-153.

Dequech D., Neoclassical, mainstream, orthodox, and heterodox economics, "Journal of Post Keynesian Economics" 2007, Vol. 30(2), pp. 279-302.

Farrell G., Well-being for all as the objective of social cohesion, in Well-being for all. Concepts and tools for social cohesion, Trends in social cohesion No. 20, Council of Europe, 2008, pp. 15-34.

Gowdy J., Erickson J.D., The approach of ecological economics, "Cambridge Journal of Economics" 2005, Vol. 29, pp. 207-222. 
Haines Ch., Reclaiming Progress by Limiting Economic Growth, "Journal of Sustainability Education" 2013, Vol. 5, pp. 1-11.

Nr 13(19)

Heilbroner R., The wordly philosophers: the lives, times and ideas of the great economic thinkers.Simon \& Schuster, 7th edition, 1999(dostęp: 20.04.2015).

Hotelling H., The economics of exhaustible resources, "The Journal of Political Economy" 1931, Vol. 2, pp. 137-175.

Lane R.E.,. Quality of life and quality of persons: a new role for government?, [in:] Offer A. (ed.), In pursuit of the quality of life, Oxford University Press, 1996.

Lawson T.,. An orientation for a green economics?, "Int. J. Green Economics" 2007, Vol. 1, pp. 250-267.

Marshall A., Priciples of economics, $8^{\text {th }}$ ed., McMillan and Co. , 1920

Millenium Ecosystem Assessment, Ecosystems and human well-being: a framework for assessment, World Resource Institute, Island Press, Washington 2003.

Mitra T. et al., Characterizing the sustainability problem in exhaustible resource model, CESifo Working Paper, N. 3758, 2012, www.cesifo.org/wp (dostęp: 15.04. 2015)

Neumayer E., Sustainability and inequality in human development and, Research Paper 2011/04, UNDP.

Phelps E.S., The good life and good economy: the humanist perspective of Aristotle, the pragmatists and vitalists; and the economic justice of John Rawls, Lectures in the annual series "Aristotle and the Moderns", New York, 2007.

Smith V.L., Costructivist and ecological rationality in economics, "The American Economic Review" 2003, Vol. 93, pp. 465-508.

Solow, R. M.. Intergenerational Equity and Exhaustible Resources, "The Review of Economic Studies" 1974, Vol. 41 (symposium issue), pp. 29-45.

Spash C.L., The development of environmental thinking in economics, "Environmental Values" 1999, Vol. 8, pp. 413-435.

Stiglitz E., Sen A., Fitoussi J-P., Report by the Commission on the Measurement of Economic Performance and Social Progress. Technical Report, Commission on the Measurement of Economic Performance and Social Progress, 2009.

Ostasiewicz K. Quality of life and sustanable development, [in:] Rusnak Z., Ostasiewicz K. (eds.), Quality of life and sustanable development, Research Papers UE, No. 308, Wrocław 2013, pp. 9-26.

Ostasiewicz K., Ostasiewicz W., Good Life: from Political to Human Economy, 2013, pp. 208-218, http://www.amse.ue.wroc.pl/proceedings.html (dostęp: 30.04.2015).

Prescott-Allen R., The wellbeing of nations, Island Press, 2001.

Victor P.A., Managing without growth. Slower by design, not disaster, Edward Elgar, Northampton 2008.

\section{PRZYSTOSOWANIE EKONOMII DO BADAŃ NAD JAKOŚCIĄ ŻYCIA}

Streszczenie: W artykule krótko scharakteryzowano ekonomię neoklasyczną, która zupełnie odeszła od ideału arystotelesowego, jakim było dobre życie. Aby żyć dobrze, ludzkość tworzyła różne instytucje, w szczególności instytucje społeczne, takie jak gospodarka, edukacja, ochrona zdrowia itp. Wszystkie instytucje i organizacje mają służyć ludziom, realizować zadania, z myślą których zostały powołane do życia. Podstawowe teorie ekonomiczne, takie jak teoria wzrostu i teoria równowagi, nie mają nic 
wspólnego z rzeczywistością. Gospodarka, tzw. wolnorynkowa, przestaje służyć społeczeństwu. Celem artykułu jest z jednej strony pokazanie na prostym przykładzie jak bardzo nierealne sa twierdzenia ekonomii, z drugiej zaś strony, jest nowa propozycja STATYSTYCZNY badań nad jakością życia. Istota nowości polega na tym, aby jakość życia była rozpatrywana jako integralna część ekonomii. Odpowiednią ekonomią do realizacji takiego celu jest ekonomia ekologiczna. W ramach takiej ekonomii proponuje się zastosować strukturalny system wskaźników charakteryzujących jakość funkcjonowania instytucji społecznych, od których zależy jakość życia ludzi, a także odzwierciedlających odczucia samych ludzi. To człowiek jest ostatecznym sędzią jakości swego bytowania.

Słowa kluczowe: jakość życia, ekonomia neoklasyczna, ekonomia ekologiczna, zrównoważony rozwój, pomiar jakości życia. 